\title{
Academic Performance of Bachelor of Science Students from Course Structure: A Study in the Faculty of Science and Technology at Suan Sunandha Rajabhat University
}

\author{
K. Bussaban and N. Prapasuwannakul
}

\begin{abstract}
This study investigates the relationship of the academic performance and the courses achievement of undergraduate students at the faculty of science and technology. Linear Regression Analysis and Pearson product Moment Correlation Coefficient are used to determine which courses are significant predictors. The correlation is being categorized from 12 curricula course structure. Data collected is from the sample of 1619 online report submitted by science graduated students who have graduated during the academic year 2013-2017. The results of the study indicate that there is a positive significant linear correlation between the course structure achievement and the academic performance in each curriculum. $100 \%$ of the curricula, require major course achievement have a significant effect on the grade point average. $92 \%$ of the curricula, elective major course and professional English courses achievement have a significant effect on the grade point average. Required major course and elective major course are quite strong relationship with academic success.
\end{abstract}

Index Terms-Academic performance, curriculum structure, learning outcome, the proportion of the variation.

\section{INTRODUCTION}

In higher education setting and from the lens of educators, any study result or formally academic achievement or performance is the learners' individual development in obtaining knowledge literacy, skills and attitudes. In addition, the academic achievement is also used as an indicator of qualitative characteristics and competencies based on the learning process standardized by higher education institutions [1], [2]. In fact, study result relates directly with various other factors and not limited to the learning process. Bloom cited in [3], identifies Learner himself or herself, Instructors, Learning Activities, and Learning Atmosphere as factors attributed to students' achievement. It can therefore be inferred that learner's academic performance is also the indicator toward any academic institution's achievement in providing the educational services [4] depicts that the Science and Technology undergraduate study results can be attributed to background knowledge or the prior academic performance. Course structure, student grades, failure rate, awards and achievement and GPA can be useful for the assessment curriculum at the end of a stage or year.Routine data gathered

Manuscript received November 25, 2018; revised April 28, 2019. This work was supported in part by Institute for Research and Development, Suan Sunandha Rajabhat University.

The authors are with Suan Sunandha Rajabhat University, Bangkok 10300, Thailand (e-mail: kanyarat.bu@ssru.ac.th, naruemon.pr@ssru.ac.th). at the end of courses can also provide a picture of the curriculum's progress. Moreover, assessment informs students' progress then before students graduate, curriculum design team need evidence that students have achieved the required learning to progress [1]. Thailand has a framework for higher education that requires graduates of all levels to meet at least five learning outcomes which are moral skill, knowledge skill, intellectual skill, interpersonal relationship and responsibilities skill, and numerical analysis, communication and information technology skill. To achieve these learning outcomes, it is necessary to design courses in a curriculum having relationship among the various subjects matter to create coherence and avoid gaps on the framework of the curriculum. A curriculum design is an important mechanism that will lead to the production of qualified graduates according to the aspiration of each course [5]. The curricula in Science and technology Faculty of Suan Sunandha Rajabhat University have designed theirs curricula structure consisting of 8 different courses which are general education courses, core courses, required major courses, elective major courses, professional English courses, management science courses, project and internship courses, and free elective courses. This organized balance the discipline knowledge with other more generic skill and attempt to develop students ability. The students should receive some indicator of how they will progress through the curriculum. To contribute to quality assurance and improve student learning, curriculum assessment is a systematic process for gathering and evaluating information on students' progress. Therefore, the study academic performance from course structure is a way of curriculum assessment in order to know how much each courses in the curriculum results in a successful completion of the course and address the challenge of coherence in curriculum organization. The objective of this study is investigates the relationship of the academic performance and the courses achievement of undergraduate students at the faculty of science and technology categorized from 12 curricula.

\section{THE STUDY}

\section{A. The Data Gathering Stage}

The primary data employed in this study is from the students' academic results reported to the university's registrar system and who are the graduates of the Faculty of Science and Technology, Suan Sunandha Rajabhat University in Thailand during the academic year 2013-2017. In fulfilling 
the study objectives, the sample of 1619 online reports submitted are used based on cluster sampling technique. The number of online reports submitted in each program are presented in Table I.

\begin{tabular}{ll} 
TABLE I: THE NUMBER OF ONLINE REPORTS SUBMITTED \\
\hline \hline Program & Sample number \\
\hline Applied Physics & 57 \\
Applied Statistics & 141 \\
Biology & 144 \\
Biotechnology & 55 \\
Chemistry & 74 \\
Computer sciences & 239 \\
Environmental Sciences & 146 \\
Food Industry and Service & 139 \\
Home Economics & 120 \\
Informatics Mathematics & 57 \\
Industrial Microbiology & 72 \\
Information Technology & 375 \\
\hline \hline
\end{tabular}

\section{B. Variables}

In this study, the Academic performance is measured by using Grade Point Average (GPA) is being assigned as a dependent variable in regression analysis. An average score level of subjects in each group (core courses, required major courses, elective major courses, professional English courses, management science courses, project and internship courses) are calculated and are used as independent variables in each curricula or the program of study .

\section{Statistical Analysis}

Pearson product Moment Correlation Coefficient is useful when the research tried to determine whether two variables are related, the strength of the relationship between the variables and what type of relationship exist. Simple and multiple linear regression are designed to summarize and study relationships between average score level of each group and grade point average and to predict the influence of $x_{\mathrm{i}}$ (course structure) on $y$ (the academic performance). The coefficient of determination or $r$-squared value denoted $r^{2}$ is use to determine percent of the variation in $y$ explained by the variation in predictor $x$ [6].Factor analysis is a multivariate statistical procedure that can use to reduce a large number of variables, [7]. Factor analysis is a method for investigating whether a number of variables of interest are linearly related to a smaller number of unobservable factors [8]. In this study, factor analysis is used to group the linearly related independent variables into factor.

\section{FINDING}

Finding of the study indicated that there was a positive significant correlation between required major courses achievement and their academic performance all programs at 0.05. Elective major courses achievement and academic performance were linearly related all programs except Industrial Microbiology program. Professional English courses achievement related with their academic performance in all programs except Food Industry and Service program. There was a positive significant correlation between core courses achievement and their academic performance all programs except Computer sciences, Environmental Sciences and Food Industry and Service programs. Project and internship courses achievement and their academic performance were linearly related all programs except Applied Physics, Biology and Informatics Mathematics programs. Management science courses achievement and academic performance were linearly related all programs except Applied Physics and Industrial Microbiology programs. The Pearson Correlation and partial correlation coefficients are presented in Table II.

TABLE II: THE CORRELATION AND PARTIAL CORRELATION COEFFICIENT

\begin{tabular}{|c|c|c|c|c|c|c|c|}
\hline & & \multicolumn{6}{|c|}{ Course structure } \\
\hline & & core & $\begin{array}{l}\text { required } \\
\text { major }\end{array}$ & $\begin{array}{l}\text { elective } \\
\text { major }\end{array}$ & $\begin{array}{l}\text { professional } \\
\text { English }\end{array}$ & $\begin{array}{l}\text { project and } \\
\text { internship }\end{array}$ & $\begin{array}{l}\text { management } \\
\text { science }\end{array}$ \\
\hline \multirow{2}{*}{ Applied Physics } & correlation & 0.660 & 0.713 & 0.519 & 0.355 & $0.204^{*}$ & $0.159 *$ \\
\hline & partial & $0.246^{*}$ & 0.393 & $0.170 *$ & 0.065 & $-0.009 *$ & $-0.070 *$ \\
\hline \multirow{2}{*}{ Applied Statistics } & correlation & 0.772 & 0.907 & 0.900 & 0.548 & 0.452 & 0.693 \\
\hline & partial & 0.404 & 0.611 & 0.667 & $0.033^{*}$ & $0.148^{*}$ & 0.485 \\
\hline \multirow{2}{*}{ Biology } & correlation & 0.261 & 0.935 & 0.845 & 0.752 & $0.170^{*}$ & - \\
\hline & partial & $0.090 *$ & 0.656 & 0.380 & 0.339 & $0.194^{*}$ & - \\
\hline \multirow{2}{*}{ Biotechnology } & correlation & 0903 & 0.937 & 0.903 & 0.763 & 0.429 & - \\
\hline & partial & 0.744 & 0.653 & 0.372 & 0.443 & 0.433 & - \\
\hline \multirow{2}{*}{ Chemistry } & correlation & 0.901 & 0.946 & 0.866 & 0.793 & 0.350 & - \\
\hline & partial & 0.635 & 0.707 & 0.341 & 0.555 & $0.090^{*}$ & - \\
\hline \multirow{2}{*}{ Computer sciences } & correlation & $0.023^{*}$ & 0.917 & 0.815 & 0.387 & 0.165 & - \\
\hline & partial & $0.005^{*}$ & 0.811 & 0.629 & 0.64 & $0.042 *$ & - \\
\hline Environmental & correlation & $0.002 *$ & 0.778 & 0.168 & 0.545 & 0.400 & - \\
\hline Sciences & partial & $0.006^{*}$ & 0.680 & $0.113^{*}$ & 0.346 & 0.284 & - \\
\hline Food Industry and & correlation & $0.01 *$ & 0.965 & 0.856 & $0.027 *$ & 0.540 & 0.672 \\
\hline Service & partial & $0.101 *$ & 0.885 & 0.305 & $0.016^{*}$ & 0.276 & 0.351 \\
\hline \multirow{2}{*}{ Home Economics } & correlation & 0.917 & 0.251 & 0.884 & 0.404 & 0.538 & 0.702 \\
\hline & partial & 0.807 & $0.076^{*}$ & 0.692 & 0.512 & $-0.023^{*}$ & 0.397 \\
\hline Informatics & correlation & 0.832 & 0.920 & 0.828 & 0.683 & $0.205^{*}$ & - \\
\hline Mathematics & partial & 0.532 & 0.350 & 0.565 & 0.185 & $0.142 *$ & - \\
\hline Industrial & correlation & 0.817 & 0.844 & $0.010^{*}$ & 0.466 & $0.205^{*}$ & 0.622 \\
\hline Microbiology & partial & 0.347 & 0.475 & $-0.112^{*}$ & $0.008 *$ & $0.029 *$ & 0.311 \\
\hline Information & correlation & 0.766 & 0.120 & 0.796 & - & 0.261 & - \\
\hline Technology & partial & 0.565 & $0.045^{*}$ & 0.63 & - & 0.211 & - \\
\hline
\end{tabular}


TABLEIII: PREDICTED LINEAR REGRESSION MODELS

\begin{tabular}{|c|c|c|c|c|}
\hline Program & Regression model & $\mathbf{R}_{\text {adj }}^{2}$ & Durbin & $\begin{array}{c}\text { Standard } \\
\text { Residual } \\
(\max )\end{array}$ \\
\hline Applied Physics & $\begin{array}{l}\mathrm{GPA}=2.947+0.253 \times(\text { factor score } 1)+0.149(\text { factor score } 2) \\
\text { factor score } 1=0.660 \mathrm{C}+0.799 \mathrm{R}+0.827 \mathrm{EN} \\
\text { factor score } 2=0.709 \mathrm{E}+0.852 \mathrm{M}\end{array}$ & 0.519 & 1.557 & 2.649 \\
\hline Applied Statistics & $\begin{array}{l}\mathrm{GPA}=2.726+0.379 \times(\text { factor score }) \\
\text { factor score } 1=0.912 \mathrm{R}+0.881 \mathrm{E}+0.851 \mathrm{C}+0.771 \mathrm{M}\end{array}$ & 0.922 & 1.680 & 2.058 \\
\hline Biology & $\begin{array}{l}\mathrm{GPA}=2.874+0.386 \times(\text { factor score }) \\
\text { factor score } 1=0.941 \mathrm{R}+0.886 \mathrm{E}+0.838 \mathrm{EN}+0.403 \mathrm{C}\end{array}$ & 0.869 & 1.590 & 1.909 \\
\hline Biotechnology & $\begin{array}{l}\mathrm{GPA}=2.758+0.426 \times(\text { factor score } 1) \\
\text { factor } \mathrm{score} 1=0.937 \mathrm{R}+0.930 \mathrm{E}+0.888 \mathrm{C}+0.825 \mathrm{EN}+0.453 \mathrm{P}\end{array}$ & 0.956 & 1.602 & 2.465 \\
\hline Chemistry & $\begin{array}{l}\mathrm{GPA}=0.508+0.809 \mathrm{R} \\
\mathrm{GPA}=2.703+0.290 \times(\text { factor score } 1)+0.091(\text { factor score } 2)\end{array}$ & 0.893 & 1.939 & 2.406 \\
\hline Computer sciences & $\begin{array}{l}\text { factor score } 1=0.939 \mathrm{E}+0.923 \mathrm{R} \\
\text { factor score } 2=0.764 \mathrm{EN}+0.738 \mathrm{P}\end{array}$ & 0.895 & 1.618 & 2.473 \\
\hline Environmental Sciences & $\begin{array}{l}\mathrm{GPA}=2.813+0.260 \times(\text { factor score } 1) \\
\text { factor score } 1=0.827 \mathrm{R}+0.745 \mathrm{EN}+0.598 \mathrm{P}\end{array}$ & 0.630 & 1.488 & 2.297 \\
\hline $\begin{array}{l}\text { Food Industry and } \\
\text { Service }\end{array}$ & $\mathrm{GPA}=0.475+0.699 \mathrm{R}+0.107 \mathrm{M}$ & 0.940 & 1.477 & 2.268 \\
\hline Home Economics & $\begin{array}{l}\mathrm{GPA}=2.898+0.321 \times(\text { factor score })+0.230(\text { factor score } 2) \\
\text { factor score } 1=0.841 \mathrm{P}+0.755 \mathrm{M}+0.693 \mathrm{E}+0.628 \mathrm{C} \\
\text { factor score } 2=0.831 \mathrm{R}\end{array}$ & 0.888 & 1.486 & 2.073 \\
\hline $\begin{array}{l}\text { Informatics } \\
\text { Mathematics }\end{array}$ & $\mathrm{GPA}=0.223+0.408 \mathrm{C}+0.480 \mathrm{E}$ & 0.908 & 1.882 & 3.159 \\
\hline Industrial Microbiology & $\mathrm{GPA}=0.935+0.679 \mathrm{R}$ & 0.712 & 1.763 & 2.169 \\
\hline Information Technology & $\mathrm{GPA}=0.962+0.665 \mathrm{E}$ & 0.632 & 1.472 & 2.124 \\
\hline
\end{tabular}

Required major courses achievement shows quite strong association with academic performance in all programs except Home Economics and Information Technology programs. Results of the linear regression analysis are presented in Table III. They indicate that are $51.9 \%$ of the variation in students' academic performance is explained by their core courses, required major courses, elective major courses, professional English courses and management science courses achievement in Applied Physics program but project and internship courses achievement is not factor for predicting the academic performance. For Applied Statistics program core courses, required major courses, elective major courses, and management science courses achievement explain the variation in students' academic performance about $92.2 \%$ but professional English courses and management project and internship courses achievement are not predicted factors. Biology students' academic performance is explained by their core courses, required major courses, elective major courses, and professional English courses achievement about $86.9 \%$ but project and internship courses achievement is not predicted factor. $95.6 \%$ of variation in Biotechnology students' academic performance is explained by core courses, required major courses, elective major courses, professional English courses, and project and internship courses achievement. $89.3 \%$ of variation in Chemistry students' academic performance is explained by only required major courses achievement. Like Chemistry program only required major courses achievement explain variation in Industrial Microbiology students' academic performance about $71.2 \%$. For Information Technology program, elective major courses achievement is only one factor which explain variation in students' academic performance. Computer sciences students' academic performance is explained by their required major courses, elective major courses, professional English courses and project and internship courses achievement about $89.5 \%$ but core courses achievement is not predicted factor. $63 \%$ of variation in Environmental Sciences students' academic performance is explained by required major courses, professional English courses, and project and internship courses achievement but core courses and elective major courses achievement are not predicted factors. 94\% of the variation in students' academic performance is explained by their required major courses, and management science courses achievement in Food Industry and Service program but core courses, elective major courses, professional English courses and project and internship courses achievement are not factor for predicting the academic performance. $88.8 \%$ of the variation in students' academic performance is explained by their core courses, required major courses, elective major courses, management science courses, project and internship courses achievement in Home Economics program but professional English courses achievement is not factor for predicting the academic performance. $90.8 \%$ of the variation in students' academic performance is explained by their core courses and elective major courses achievement in Informatics Mathematics program but required major courses, professional English courses and project and internship courses achievement are not factors for predicting the academic performance. The courses achievement predictors in each program are presented in Table IV. The showed that there is no course being predictor in all program but required 
major course is the strong factor effect on the grade point average. $75 \%$ of the curricular, the grade point average resulted from required major course achievement. On the other hand, project and internship course and professional English courses achievement is not important role of predictor.

TABLE IV: THE PREDICTOR IN EACH PROGRAM

\begin{tabular}{|c|c|c|c|c|c|c|}
\hline \multirow[b]{2}{*}{ Program } & \multicolumn{6}{|c|}{ Course structure } \\
\hline & core & $\begin{array}{l}\text { required } \\
\text { major }\end{array}$ & $\begin{array}{l}\text { elective } \\
\text { major }\end{array}$ & $\begin{array}{l}\text { professional } \\
\text { English }\end{array}$ & $\begin{array}{l}\text { project and } \\
\text { internship }\end{array}$ & $\begin{array}{l}\text { management } \\
\text { science }\end{array}$ \\
\hline Applied Physics & $\sqrt{ }$ & $\sqrt{ }$ & $\sqrt{ }$ & $\sqrt{ }$ & $\times$ & $\sqrt{ }$ \\
\hline Applied Statistics & $\sqrt{ }$ & $\sqrt{ }$ & $\sqrt{ }$ & $x$ & $x$ & $\sqrt{ }$ \\
\hline Biology & $\sqrt{ }$ & $\sqrt{ }$ & $\sqrt{ }$ & $\sqrt{ }$ & $x$ & - \\
\hline Biotechnology & $\sqrt{ }$ & $\sqrt{ }$ & $\sqrt{ }$ & $\sqrt{ }$ & $\sqrt{ }$ & - \\
\hline Chemistry & $x$ & $\sqrt{ }$ & $x$ & $x$ & $x$ & - \\
\hline Computer sciences & $x$ & $\sqrt{ }$ & $\sqrt{ }$ & $\sqrt{ }$ & $\sqrt{ }$ & - \\
\hline Environmental Sciences & $x$ & $\sqrt{ }$ & $x$ & $\sqrt{ }$ & $\sqrt{ }$ & - \\
\hline Food Industry and Service & $x$ & $\sqrt{ }$ & $x$ & $\times$ & $x$ & $\sqrt{ }$ \\
\hline Home Economics & $\sqrt{ }$ & $x$ & $\sqrt{ }$ & $x$ & $\sqrt{ }$ & $\sqrt{ }$ \\
\hline Informatics Mathematics & $\sqrt{ }$ & $x$ & $\sqrt{ }$ & $x$ & $x$ & - \\
\hline Industrial Microbiology & $x$ & $\sqrt{ }$ & $x$ & $x$ & $x$ & $x$ \\
\hline Information Technology & $x$ & $x$ & $\sqrt{ }$ & - & $x$ & - \\
\hline
\end{tabular}

$\sqrt{ }$ present the predictor, $\times$ present not predictor, - present do not have this course in program

\section{CONCLUSIONS}

This study aims at identifying the correlation among academic performance and the success in taking subjects in each course structure and to confirm that the latter has direct influence and impact on the former for the graduates of Science curricula in offer. The result of conducting the study depicts the correlation of success in taking subjects in the course structure and the academic achievement using Grade Point Average (GPA) represented in linear shape. The tendency of high correlation is appeared in the Food Industry and Service, Biotechnology, Applied Statistics, Informatics Mathematics, Computer sciences, Chemistry, Home Economics and Biology program of study representing linearity of $r^{2}>0.8$. Furthermore, the study does further support that success in taking subjects in required major course, core course and elective major courses can be employed to predict the academic achievement of students. However, the design and development of the curricula program play a critical role in students' learning experience and all subjects in curriculum are crucial in realizing learning objective [5]. Curriculum design should develop efficient studying skills in order for learning objectives to become actual learning outcome [9]. In order to achieve the objectives of the course, Curriculum development team can consider the results of this study are preliminary data for in-depth analysis and design course structure In terms of scope, Sequence, Continuity, Integration, Articulation and balance[1]. Since core course and some subjects in required major course are offered during the first or second year of study, the success in taking these subjects are inevitably of vital source of preliminary indicator in providing necessary assistance to the student taking any program of study.

\section{ACKNOWLEDGMENT}

The authors wish to acknowledge their grateful appreciation for the financial subsidy provided by Suan
Sunandha Rajabhat University.

\section{REFERENCES}

[1] G. O'Neill, Curriculum Design in Higher Education: Theory to Practice, Dublin: UCD Teaching \& Learning, 2015, ch 6.

[2] P. Cheewaprakokit, "Study of factor aanlysis affecting academic acchiement of undergratduate stusents in international program," in Proc. the International Multiconference of Engineers and Computer Scientists, 2013.

[3] S. Vinijlul, "Relationship between academic admission scores and academic achievement of students of Kuakarun Faclty of Nursing Navamindradhiraj University," Kuakarun Journal of Nursing, pp. 94-107, vol. 21, December 2014.

[4] K. Bussaban and N. Prapasuwannakul, "Probability model for predicting different level of academic success in students of Faculty of Science and Technology," Turkish Online Journal of Educational Technology, pp. 264-267, December, 2016.

[5] L. Jessica, "The influence of curriculum quality on student achievement on the New Jersey assessment of skills and knowledge (NJ ASK) language arts and mathematics for fifth-grade students in the Lowest socioeconomic school districts," Doctor of Education, Dissertations and Theses, Seton Hall University (ETDs), 2017.

[6] G. Keller, Staistics for Management and Economics Abbreviated ( $^{\text {th }}$ ed), Thson South-Western, China, 2007.

[7] B. Williams, A. Onsman, and T. Brown, "Exploratory factor analysis: A five-step guide for novices," Journal of Emergency Primary Health Care (JEPHC), vol. 8, issue 3, 2010.

[8] P. Tryfos, Business Statistics, McGraw-Hill Inc.US, 1989, ch 14.

[9] S. Demir, M. Kilinc, and A. Dogan, "The effect of curriculum for developing efficient studying skills on academic achievments and studing skills of learning," International Electronic Journal of Elementary Education, pp. 427-440, vol. 4, no. 3, 2012.

Copyright $\odot 2019$ by the authors. This is an open access article distributed under the Creative Commons Attribution License which permits unrestricted use, distribution, and reproduction in any medium, provided the original work is properly cited (CC BY 4.0).

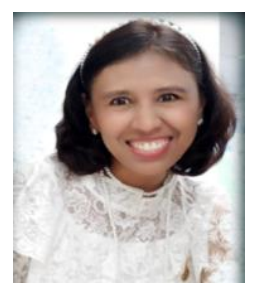

Kanyarat Bussaban was born in Nakhon $\mathrm{Si}$ Thammarat, Thailand on January 28, 1970. She received her BSc degree in mathematics education, 1992 from Suan Sunandha Teacher College and the M.S.in statistics, 1997 from Kasetsart University Bangkok, Thailand.

She has been working as a lecturer at the Department of Informatics Mathematics, Suan 
Sunandha Rajabhat University, Bangkok,Thailand since 1998. Her previous publications are as follows

1. Bussaban K.,Chumee J.,From Coconut Husk Waste to Community Business, Advances in Intelligent Systems and Computing Volume 783 (2019) ,pp. 229-238.

2. Bussaban K., Prapasuwannakul., "Probability Model for Predicting Different Level of Academic Success in Students of Faculty of science and Technology" Turkish Online Journal of Educational Technology (Specia Issue, Dec. 2016) ,PP. 264-267,(2016).

3. Bussaban K., Waraporn P., "Preparing undergraduate students majoring in Computer Science and Mathematics with Data Science perspectives and awareness in the age of Big Data" Procedia- Social and Behavioral Sciences Vol:197, pp.1443-1446, (2015).

4. Bussaban K., Poolsuwan S "Welfare State and Income Distribution to School-Age Children" International Journal of Social, Management, Economics and Business Engineering Vol:8 No:5, (2014).

5. Bussaban K., Kularbphettong K., "Analysis of Users' Behavior on Book Loan Log Based On Association Rule Mining" International Journal of Computer, Information, Systems and Control Engineering Vol:8 No:1, (2014).

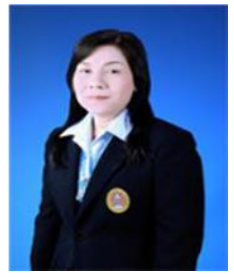

Naruemon Prapasuwannakul got a bachelor of science (BSc) in microbiology from Chulalongkorn University, Bangkok, Thailand in 1981 and a master of applied science (MAppSc) in food engineering from University of New South Wales, Sydney, Australia in 1989.

She has been working as a lecturer at the Department of Food Science and Technology, Suan
Sunandha Rajabhat University, Bangkok, Thailand since 1998. Her previous publications are :

1. N. Prapasuwannakul and M. Panbualuang, "Evaluation of thermal processing for reduction of Salmonella spp. and Escherichia coli in pork sausage wrapped in banana leaves," presented at the Conference of International of Arts and Sciences, Toronto, Canada, June 5-8, 2017.

2. N. Prapasuwannakul and K. Bussaban, "The proportion of the variation in the academic performance form the courses achievement of Food Science and Technology students," Proceedings book of International Conference on New Horizons in Education, ed. Aytekin İSMAN \& Ahmet ESKICUMALI, pp. 864-867, vol.3, November 2017.

3. K. Bussaban and Prapasuwannakul, "Probability Model for Predicting Different Level of Academic Success in Students of Faculty of science and Technology" Turkish Online Journal of Educational Technology (Special Issue, Dec. 2016) ,PP. 264-267,(2016).

Assistant Professor Naruemon Prapasuwannakul is a membership of Food Science and Technology Association of Thailand. 